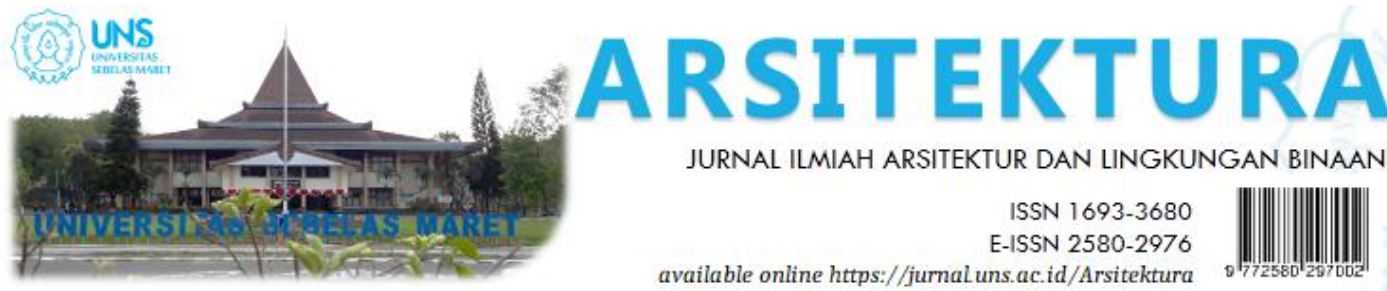

Volume 18 Issue 1 April 2020, pages: 01-12

\title{
Kajian Implementasi Desain Universal Pada Taman Samarendah
}

\section{Study of The Implementation of Universal Design in Taman Samarendah}

\author{
Mafazah Noviana ${ }^{1}$, Zakiah Hidayati ${ }^{2}$ \\ Program Studi Arsitektur Politeknik Negeri Samarinda ${ }^{1 *}$ \\ Email: mnoviana@polnes.ac.id \\ Program Studi Arsitektur Politeknik Negeri Samarinda ${ }^{2}$
}

DOI: https://doi.org/10.20961/arst.v18i1.37343

Received: December 3, 2019 Revised: March 5,2020 Accepted: March 7,2020 Available online:April 30,2020

\begin{abstract}
City Parks in terms of social functions can be used as a place for social interaction, a means for sports, play and recreation. As a public facility, city parks must accommodate all groups of people, ranging from normal people, children, disabled people and the elderly. One way to provide facilities for all visitors is to apply universal design principles. Universal design aims to facilitate everyone's life through the creation of products, the built environment and communication to be used by as many people as possible and provide added value for everyone. The purpose of this study is to examine the implementation of universal design principles in Taman Samarendah.The location of the study was in Taman Samarendah, using a descriptive qualitative research method. Seven principles of universal design and Permen PUPR No.14/PRT/2017 becomes the guideline and standardization in this study. The results of this study indicate that Samarendah Park has not fully applied the universal design principles and accessibility standards. The most universal principles of design that are not applied are the principle of tolerance for error and the principle of low physical effort. The principle that is most widely applied is the size and space for approach.
\end{abstract}

Keywords: accessibility, Taman Samarendah, universal design

\section{PENDAHULUAN}

Kota merupakan kesatuan antara lingkungan fisik kota dan warga kota, tidak hanya sekedar kumpulan gedung-gedung dan sarana fisik lainnya. Sering kali keadaan lingkungan perkotaan menjadi berkembang secara ekonomi, namun menurun secara ekologi. Salah satu usaha untuk menata dan memperbaiki lingkungan melalui pembangunan Ruang Terbuka Hijau (RTH).
Berdasarkan Permen PU No. 5 Tahun 2008 tentang Pedoman Penyediaan dan Pemanfaatan Ruang Terbuka Hijau di kawasan perkotaan bahwa setiap kota di Indonesia menyediakan RTH minimal sebesar 30\% dari luas wilayah kota. Di dalam RTRW Kota Samarinda 20142034 ruang terbuka hijau publik yang ada saat ini hanya sebesar 22,93\%. Untuk itu Pemerintah Kota Samarinda terus berupaya untuk memenuhi ketentuan tersebut dengan membangun beberapa taman kota. 
Taman kota merupakan salah satu bentuk ruang luar publik yang dapat digunakan secara langsung untuk kegiatan warga kota tanpa dipungut biaya. Untuk itu taman kota harus dapat mengekspresikan dirinya sebagai tempat (place) untuk melakukan berbagai kegiatan penggunanya. (Budiyanti, 2018). Taman kota secara umum mempunyai dua fungsi, yakni fungsi ekologis dan fungsi sosial. Dari segi ekologis, taman kota berfungsi sebagai penjaga kualitas lingkungan kota. Sementara dari segi fungsi sosial taman kota bisa dijadikan tempat interaksi sosial, sarana untuk berolah raga, bermain dan rekreasi. Sebagai fasilitas yang bersifat publik, taman kota harus mengakomodasi seluruh kelompok masyarakat, mulai dari yang memiliki kondisi normal, anak kecil, penyandang cacat (difable) dan lansia. Salah satu cara untuk dapat menyediakan fasilitas yang mampu memenuhi seluruh kebutuhan tersebut yaitu dengan menerapkan tujuh prinsip desain universal. Pada hakekatnya semua manusia mempunyai hak yang sama untuk dapat menikmati fasilitas publik, salah satunya adalah taman kota.

Desain universal bertujuan untuk memudahkan hidup setiap orang melalui penciptaan produk, lingkungan binaan dan komunikasi untuk dapat digunakan sebanyak mungkin orang dan memberi nilai tambah bagi setiap orang dari berbagai usia dan kemampuan. Keberadaan ruang publik di Samarinda belum sepenuhnya memperhatikan aksesibilitas lingkungan yang sejalan dengan prinsip desain universal sehingga sulit untuk dinikmati oleh kaum difabel. Padahal jumlah penyandang difabel di Samarinda sekitar 2000 orang lebih, dari sekitar 10 ribu penyandang difabel di Kalimantan Timur. Oleh karena itu perlu dilakukan penelitian untuk mengidentifikasi permasalahan berkaitan dengan implementasi prinsip desain universal pada taman kota yang ada di Kota Samarinda.

\subsection{Taman Kota}

Taman kota adalah lahan terbuka yang berfungsi sosial dan estetik sebagai sarana kegiatan rekreatif, edukasi atau kegiatan lain pada tingkat kota. Taman kota ditujukan untuk melayani penduduk satu kota atau bagian wilayah kota. Taman ini melayani minimal 480.000 penduduk dengan standar minimal 0,3 m2 per penduduk kota, dengan luas taman minimal $144.000 \mathrm{~m} 2$. Taman ini dapat berbentuk sebagai RTH (lapangan hijau), yang dilengkapi dengan fasilitas rekreasi dan olah raga, dan kompleks olah raga dengan minimal RTH $80 \%$ - 90\%. Semua fasilitas tersebut terbuka untuk umum. Suatu taman kota dapat menciptakan sense of place, menjadi sebuah landmark, dan menjadi titik berkumpulnya komunitas. Disamping itu, taman kota juga dapat meningkatkan nilai properti dan menjadi pendorong terlaksananya pembangunan. Taman kota seharusnya menjadi komponen penting dari pembangunan suatu kota yang berhasil menurut Garvin et al, dalam Error!

\section{Reference source not found.}

Taman kota harus mampu menciptakan ruangruang yang dinamis untuk kebutuhan berbagai penggunanya, seperti ruang untuk berkumpul bermain anak sehingga membangun dan membangkitkan pengalaman yang menyenangkan. Error! Reference source not found.

Untuk meningkatkan kualitas peran dan fungsi taman kota sebagai ruang public, maka taman kota harus dilengkapi dengan fasilitas untuk rekreasi, interaksi, olah raga dan edukasi untuk segala usia termasuk para penyandang cacat, sehingga terwujudnya keragaman kegiatan pengunjung. Cohen, dkk dalam Error! Reference source not found.

\subsection{Desain Universal}

Menurut Permen PUPR No. 14 tahun 2017, desain universal adalah rancangan bangunan gedung dan fasilitasnnya yang dapat digunakan oleh semua orang secara bersamasama tanpa diperlukan adaptasi atau perlakuan khusus. Prinsip Desain Universal dikembangkan pada tahun 1997 oleh sebuah kelompok kerja yang terdiri dari arsitek, desainer produk, insinyur dan peneliti desain lingkungan, yang dipimpin oleh Ronald Mace dari North Carolina State University. Tujuan dari prinsip ini adalah untuk memandu desain lingkungan, produk dan komunikasi. Menurut Center for Universal Design di NCSU, prinsip desain universal dapat diterapkan untuk mengevaluasi desain yang ada, membimbing proses desain dan mendidik desainer dan konsumen tentang karakteristik produk yang 
lebih bermanfaat dan lingkungan. (Masruroh, Mauliani, \& Anisa, 2015).

Tujuh prinsip desain universal menurut Story dalam (Keumala \& Nanda, 2016) yaitu :

1. Equitable use (dapat digunakan oleh setiap orang). Desain berguna dan dapat dipasarkan kepada orang-orang dengan beragam kemampuan.

2. Flexibility in use (fleksibilitas dalam penggunaan) Desain mengakomodasi semua jenis pengguna dan berbagai kemampuan individu.

3. Simple and intuitive use (desain yang sederhana dan mudah digunakan). Penggunaan desain mudah dimengerti, ditinjau dari segi pengelaman dan kemampuan pengguna.

4. Perceptible information (informasi yang memadai) Produk desain dilengkapi informasi pendukung yang penting untuk pengguna dimana informasi yang diberikan sesuai dengan kemampuan pengguna.

5. Tolerance for error (toleransi kesalahan). Meminimalisasi bahaya dan konsekuensi yang merugikan dari tindakan disengaja atau tidak disengaja.

6. Low physical effort (upaya fisik rendah) Desain dapat digunakan secara efisien dan nyaman dan dengan meminimalisasi resiko kecelakaan.

7. Size and space for approach and use (ukuran dan ruang untuk pendekatan dan penggunaan). Penggunaan ukuran ruang dalam desain yaitu dengan melakukan pendekatan melalui postur, ukuran dan pergerakan pengguna.

\subsection{Difable}

Difable merupakan akronim dari dua Bahasa Inggris Different Ability yang berarti kemampuan yang berbeda. Istilah ini muncul untuk menggantikan istilah penyandang cacat yang diskriminatif dan melihat manusia sebagai sosok yang dapat dikelompokkan ke dalam kelompok normal dan tidak normal hanya berdasarkan kelengkapan kondisi fisiknya. (Kurniawan, Harry, 2014). Kelompok-kelompok yang memiliki keterbatasan fisik dan gerak (difabel) tersebut, meliputi: penyandang cacat, orang-orang tua dengan keterbatasan kekuatan fisik dan gerak, anak-anak kecil dan ibu-ibu hamil/ibu membawa anak kecil.

Penyandang Disabilitas adalah setiap orang yang mengalami keterbatasan fisik, intelektual, mental, dan/atau sensorik dalam jangka waktu lama yang dalam berinteraksi dengan lingkungan dapat mengalami hambatan dan kesulitan untuk berpartisipasi secara penuh dan efektif dengan warga negara lainnya berdasarkan kesamaan hak. (Permen PUPR No. 14 tahun 2017).

Rancangan dari ruang terbuka publik yang selama ini kebanyakan dilakukan dengan menggunakan orang yang dapat bergerak normal dan dengan ukuran rata-rata sebagai asumsi, menyebabkan banyak pengguna potensial tidak dapat ikut memasuki dan menggunakan ruang terbuka publik, karena mereka mendapatkan hambatan/barriers. (Dewang \& Leonardo, 2010).

\section{METODE}

Penelitian ini merupakan field research, yaitu penelitian lapangan, yang pengumpulan datanya dilakkukan di lapangan untuk mengadakan pengamatan terhadap suatu fenomena dalam suatu keadaan alamiah. Susanto dalam (Irkhamiyati, 2017).

Metode yang digunakan dalam penelitian ini adalah penelitian deskriptif kualitatif. Penelitian deskriptif kualitatif berusaha menggambarkan suatu gejala sosial yang bertujuan untuk menggambarkan sifat sesuatu yang tengah berlangsung pada saat studi. Metode kualitatif ini memberikan informasi yang lengkap sehingga bermanfaat bagi perkembangan ilmu pengetahuan serta lebih banyak dapat diterapkan pada berbagai masalah.

Lokasi penelitian yaitu di Taman Samarendah, merupakan taman kota yang saat ini sedang banyak mendapat perhatian masyarakat Kota Samarinda. Taman Samarendah terletak di Jalan Bhayangkara,

Teknik pengumpulan data dalam penelitian ini meliputi :

1. Observasi Lapangan. Observasi lapangan dilakukan untuk memperoleh data-data mengenai fasilitas-fasilitas yang ada di objek penelitian. Pengumpulan data 
lapangan dilakukan dengan foto-foto dan pengukuran lapangan.

2. Wawancara. dilakukan kepada narasumber yang berkaitan langsung dengan permasalahan, seperti penyandang difable, instansi terkait dan masyarakat. Hal ini bertujuan untuk mengetahui kenyamanan dan keamanan pengguna dalam menggunakan fasilitas taman kota.

3. Studi Literatur. Studi ini mengumpulan data sekunder, baik berupa peraturan pemerintah, jurnal dan buku, foto maupun gambar yang berkaitan dengan prinsip desain universal. Standarisasi yang digunakan untuk menganalisis adalah tujuh prinsip desain universal dan permen PUPR No. 14 tahun 2017.

Metode Analisis Data, terdiri dari :

1. Metode analisis data deskripsi. Analisis deskriptif bertujuan untuk menggambarkan masalah yang ditemukan pada saat penelitian dilakukan.

2. Metode analisis data komparatif

Data-data yang sudah diperoleh disusun dan kemudian dianalisis dengan membandingkan data observasi lapangan dengan data literatur. Metode komparatif digunakan untuk memperoleh kelebihan serta kekurangan yang ada pada objek penelitian.

Dari hasil observasi lapangan, data dikelompokkan berdasarkan elemen taman kota, kemudian data tersebut dilakukan analisis untuk mengetahui kesesuaian dengan standar aksesibilitas dan prinsip desain universal. Setelah itu kemudian dibuat arahan desain sebagai solusi terhadap temuan yang didapat.

\section{HASIL DAN PEMBAHASAN}

\subsection{Identifikasi Fisik Lingkungan}

Taman Samarendah merupakah salah satu taman yang terletak di pusat Kota Samarinda, Provinsi Kalimantan Timur, yang dibangun pada tahun 2014 dengan luas lahan sekitar 1,4 hektar. Taman Samarendah memiliki fungsi sebagai ruang terbuka publik tempat masyarakat Kota Samarinda berinteraksi dengan melakukan berbagai macam aktivitas, seperti olah raga, rekreasi dan kegiatan seni budaya. Taman ini berada di kawasan pelayanan perdagangan dan jasa, tepatnya di Jalan Bhayangkara Kelurahan Bugis Kota Samarinda, dilengkapi dengan beberapa fasilitas antara lain: jogging track sebagai sarana untuk berolahraga, tempat duduk untuk bersantai, lampu hias dan air mancur sebagai objek berfoto warga Kota Samarinda.

\subsubsection{Akses Masuk}

Pengunjung yang akan memasuki Taman Samarendah dapat melalui 4 sisi taman yang terbuka dan berbatasan langsung dengan jalan raya. Masing-masing sisi terdiri dari dua buah akses dengan bentuk yang sama yaitu berupa tangga dan ramp. Tangga dan ramp yang ada belum sepenuhnya memenuhi standar aksesibilitas. Akses dari parkir menuju ke pintu masuk cukup menyulitkan terutama pada saat ramai pengunjung, karena di sekitar pintu masuk tersebut ditutupi oleh parkir kendaraan terutama kendaraan roda 4.

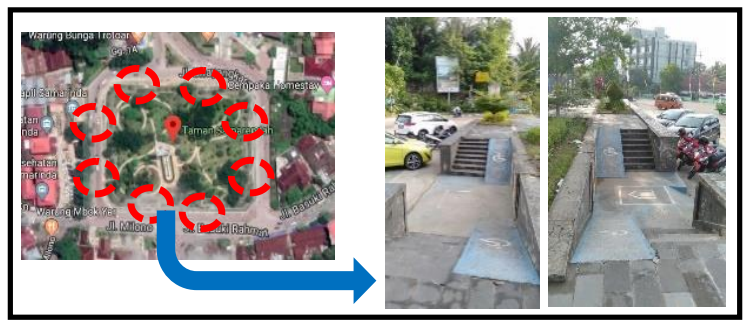

Gambar 1. Peta sebaran lokasi akses masuk ke area Taman Samarendah

\subsubsection{Area Parkir}

Parkir terdapat di sekeliling area taman berada tepat di tepi jalan umum dengan intensitas kendaraan yang tinggi, sehingga cukup membahayakan bagi pengguna terutama yang memiliki keterbatasan fisik. Terdapat tiga jenis parkir yaitu: parkir mobil, parkir motor dan parkir sepeda, namun garis penanda batas parkir sudah terlihat memudar sehingga agak sulit untuk dilihat. Ukuran parkir untuk mobil sudah sesuai dengan standar, jumlah parkirnya juga sudah cukup memadai. Untuk parkir motor dan sepeda tidak ada garis penandanya sehingga pengunjung memarkir kendaraannya cenderung tidak teratur.

Area Taman Samarendah belum menyediakan parkir khusus difabel. Untuk pencapaian dari 
tempat parkir menuju ke area taman tidak disediakan jalur khusus (trotoar) dan jalur pemandu, hal ini cukup menyulitkan pengguna yang akan mengakses ke dalam area taman, terutama bagi pengguna kursi roda dan tuna netra. Masyarakat umum yang akan masuk ke area taman sangat riskan bersinggungan dengan kendaraan lain yang sedang melintas di sekitar kawasan, karena posisi parkir yang berada persis di tepi jalan raya.
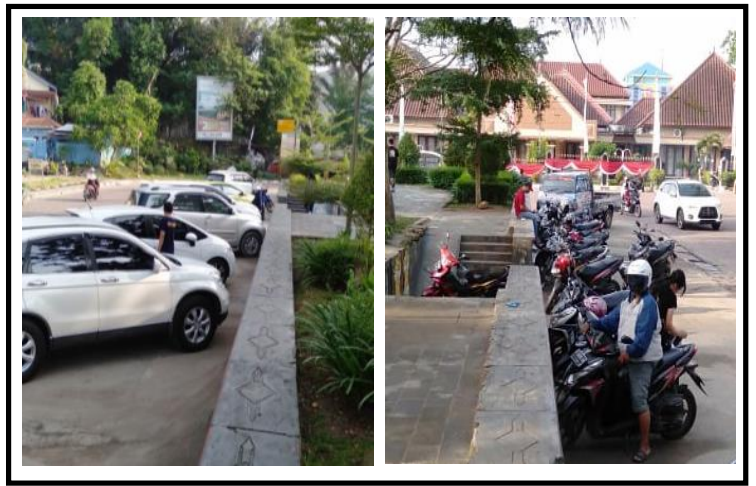

Gambar 2. Area parkir

\subsubsection{Tangga}

Taman Samarendah memiliki 15 buah tangga yang terletak di sekeliling area taman. Semua tangga yang ada memiliki bentuk dan ukuran yang sama, yaitu lebar tangga $120 \mathrm{~cm}$, tinggi anak tangga $15 \mathrm{~cm}$, dan lebar anak tangga 30 $\mathrm{cm}$, namun semuanya tangga tidak dilengkapi dengan handrail. Kemiringan anak tangga kurang lebih 300. Tangga-tangga yang ada hanya menggunakan cor semen tidak diberi keramik sehingga permukaannya tidak terlalu licin.

Tangga yang dari ukuran yang ada sudah sesuai dengan standar aksesibitas, namun secara kelengkapannya belum memenuhi karena pada tepinya belum ada material anti slip dan tidak dilengkapi dengan handrailing. Kondisi tangga seperti ini masih dapat digunakan oleh orang yang menggunakan kruk dan juga lansia meskipun tidak terlalu memenuhi aspek kemudahan.

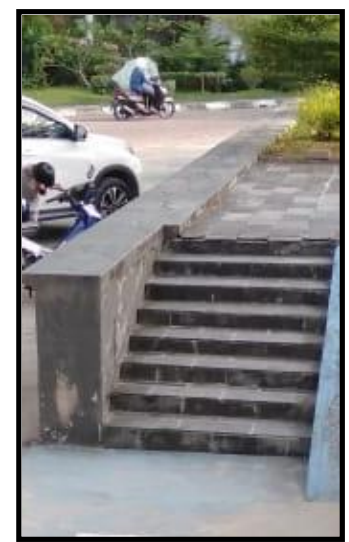

Gambar 3. Tangga pada akses masuk

\subsubsection{Ramp}

Taman Samarendah telah dilengkapi dengan ramp yang diletakkan di sekeliling area taman sebagai akses menuju ke area taman. Terdapat dua jenis ramp, yang tipe 1 memiliki lebar 80 $\mathrm{cm}$, dengan kemiringan kurang lebih 300 namun tidak dilengkapi dengan handrail. Ramp jenis ini berjumlah 15 buah yang letaknya menyebar di sekeliling area taman. Sedangkan ramp tipe 2 memiliki lebar $180 \mathrm{~cm}$, dengan kemiringan kurang lebih 200, dan dilengkapi dengan handrailing. Semua ramp yang ada menggunakan material semen yang permukaan kasar serta dilengkapi dengan simbol aksesibilitas untuk difable.

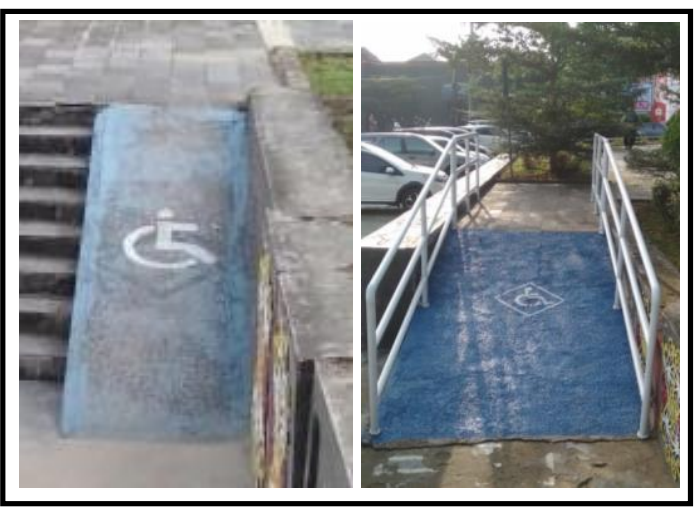

Gambar 4. Ramp di Taman Samarendah

Berdasarkan ukurannya, kedua tipe ramp yang ada sudah sesuai dengan ukuran standar aksesibilitas, hanya kemiringannya yang terlalu curam. Ramp tipe 1 cukup sulit diakses oleh orang yang memiliki keterbatasan fisik seperti lansia dan pengguna kursi roda, karena kemiringannya yang cukup curam dan belum dilengkapi dengan handrailing. Ramp tipe 2 
cukup mudah diakses oleh orang yang memiliki.keterbatasan fisik, karena sudah dilengkapi dengan handrailing dan kemiringannya lebih landai dibanding dengan ramp tipe 1.

\subsubsection{Jalur Pedestrian}

Bentuk jalur pedestrian di dalam area Taman Samarendah menggunakan bentuk- bentuk kurva yang menyebar ke seluruh taman. Jalur pedestrian ini selain digunakan oleh masyarakat untuk berjalan-jalan menikmati suasana namun juga sekaligus berfungsi sebagai jogging track. Terdapat 2 tipe pedestrian yang ada di area taman berdasarkan penggunaan material, yaitu: pedestrian dengan material paving block dan pedestrian dengan material coral sikat. Sedangkan berdasarkan ukuran, pedestrian di Taman Samarendah terdiri dari 3 tipe yaitu: pedestrian dengan lebar $270 \mathrm{~cm}, 180 \mathrm{~cm}$ dan $120 \mathrm{~cm}$.

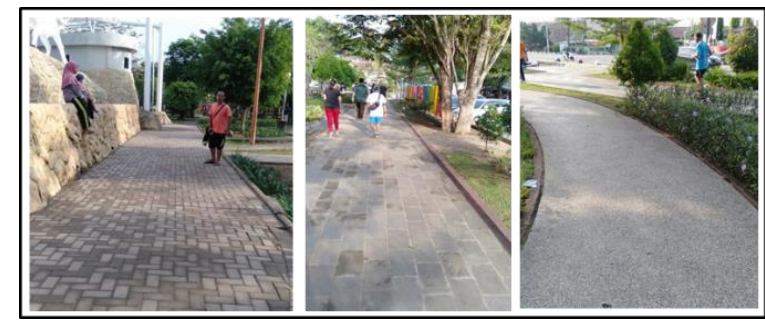

Gambar 5. Jalur pedestrian taman

Pada sepanjang jalur pedestrian di Taman Samarendah tidak dilengkapi dengan jalur pemandu untuk aksesibilitas tuna netra. Jalur pedestrian yang ada cukup mudah untuk dilalui oleh pengguna kruk, kursi roda, lansia maupun anak-anak, karena memiliki ukuran yang telah sesuai dengan standar desain universal dan permukaan perkerasannya relatif rata. Namun terdapat beberapa hambatan yang menyulitkan untuk digunakan oleh pengguna kursi roda yaitu adanya jalur pedestrian yang terputus karena adanya perbedaan ketinggian pedestrian dan juga adanya saluran drainase yang menjorok ke jalur pedestrian yang cukup mengganggu sirkulasi pengguna taman. Seharusnya jalur pedestrian merupakan sirkulasi yang menerus tidak boleh terputus dan mengarah ke semua fasilitas taman dan furniture taman seperti bangku taman dan tempat sampah, sehingga mudah digunakan oleh semua orang tanpa terkecuali.

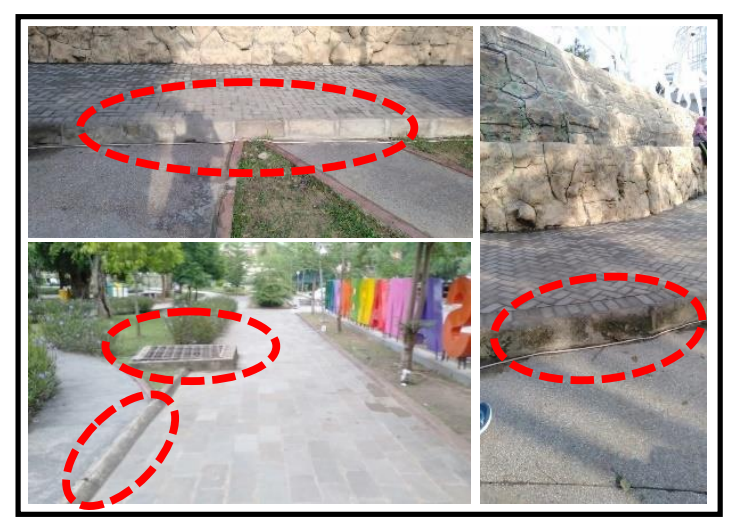

Gambar 6. Hambatan pada jalur pedestrian

\subsubsection{Bangku Taman}

Taman Samarendah menyediakan 2 jenis bangku taman, yaitu bangku yang terbuat dari cor beton dan terbuat dari kayu. Bangku taman tipe 1 terbuat dari material cor beton, memiliki ukuran panjang kursi $150 \mathrm{~cm}$, tinggi dudukan $55 \mathrm{~cm}$ dan lebar dudukan $50 \mathrm{~cm}$. Sedangkan bangku taman tipe 2 terbuat dari material kayu, dengan ukuran tinggi dudukan $40 \mathrm{~cm}$ dan diameter dudukan $30 \mathrm{~cm}$. Bangku tipe 2 ini kondisinya sangat tidak terawat dan rusak pada beberapa bagiannya.

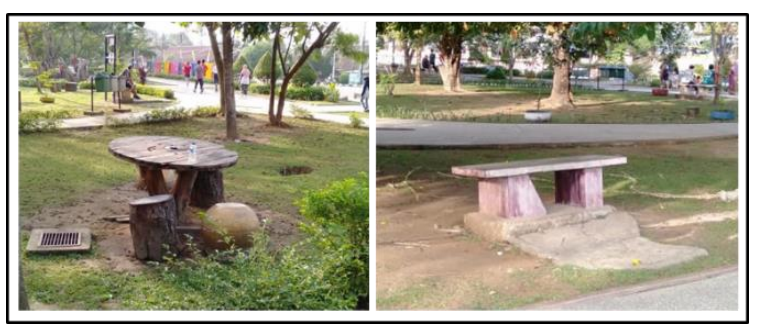

Gambar. 6 Bangku Taman

\subsubsection{Rambu dan Marka}

Rambu dan marka pada sebuah kawasan sangat penting terkait dengan aksesibilitas lingkungan. Di area Taman Samarendah hanya terdapat simbol aksesibilitas bagi disabilitas pada ramp, pada bagian lain tidak ditemukan marka penanda penyandang disabilitas. Ramba dan marka lain seperti rambu peringatan, penunjuk arah, penanda fasilitas tidak ditemukan sama sekali. Hal ini menyebabkan tidak tersedianya informasi yang lengkap, sehingga dapat menimbulkan kebingungan pengunjung saat berada di area taman, terutama untuk pengunjung yang memiliki keterbatasan fisik. 


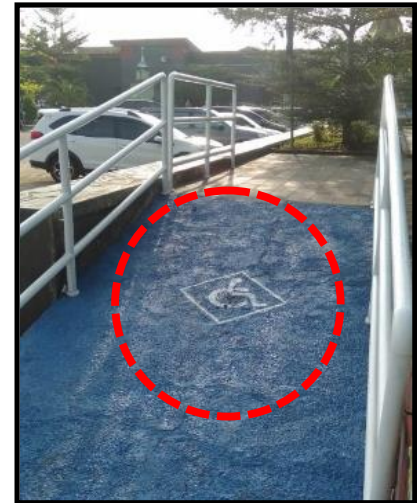

Gambar 7. Simbol difable pada ramp

\subsection{Analisis Implementasi Desain Universal}

Dari uraian di atas dapat diketahui bahwa elemen-elemen yang ada di Taman Samarendah belum sepenuhnya sesuai dengan standar yang telah ditentukan oleh pemerintah melalui Permen PUPR No. 14 tahun 2017. Berikut ini tabel kesimpulan tentang aksesibilitas pada Taman Samarendah.

Tabel 1. Hasil Analisis Aksesibilitas Taman Samarendah

\begin{tabular}{|c|c|c|}
\hline Elemen & Ketentuan Teknis & Kondisi \\
\hline \multirow[t]{2}{*}{$\begin{array}{l}\text { Area } \\
\text { Parkir }\end{array}$} & $\begin{array}{l}\text { Dilengkapi } \\
\text { penunjuk arah dan } \\
\text { penanda yang jelas } \\
\text { Tersedia parkir } \\
\text { penyandang } \\
\text { disabilitas yang } \\
\text { diberi simbol } \\
\text { dengan kelandaian } \\
\text { maksimal } 2^{0} \text {, lebar } \\
370 \mathrm{~cm}\end{array}$ & $\begin{array}{lr}\text { Parkir } & \text { tidak } \\
\text { memenuhi standar } & \\
\text { aksesibilitas } & \\
\text { karena } & \text { tidak } \\
\text { dilengkapi } & \\
\text { penanda } & \text { yang } \\
\text { jelas serta tidak } \\
\text { disediakanya } \\
\text { parkir khusus } \\
\text { disabilitas }\end{array}$ \\
\hline & Kesimpulan & $\begin{array}{l}\text { Aksesibilitas } \\
\text { kurang }\end{array}$ \\
\hline \multirow[t]{2}{*}{ Tangga } & $\begin{array}{l}\text { Tinggi anak tangga } \\
\text { maks. } 18 \mathrm{~cm} \text { dan } \\
\text { min.15 cm, \& } \\
\text { lebarnya min. } 30 \\
\mathrm{~cm} \text {. Material tidak } \\
\text { licin dan tepinya } \\
\text { diberi anti slip. } \\
\text { Kemiringan maks. } \\
35^{0} \text { Dilengkapi } \\
\text { handrail }\end{array}$ & $\begin{array}{l}\text { Ukuran tangga } \\
\text { sesuai dengan } \\
\text { standar } \\
\text { aksesibilitas, } \\
\text { hanya tidak } \\
\text { tersedia handrail.. }\end{array}$ \\
\hline & Kesimpulan & $\begin{array}{l}\text { Aksesibilitas } \\
\text { cukup }\end{array}$ \\
\hline Ramp & $\begin{array}{l}\text { Lebar min. } 120 \mathrm{~cm} \\
\text {, kelandaian maks } \\
6^{\text {o. }} \text { Lebar } \\
\text { min } \quad 95 \quad \text { efektif } \\
\text { Permukaan }\end{array}$ & $\begin{array}{l}\text { Lebar ramp sesuai } \\
\text { standar } \\
\text { aksesibilitas, } \\
\text { dilengkapi } \\
\text { handrail. }\end{array}$ \\
\hline
\end{tabular}

\begin{tabular}{|c|c|c|}
\hline & $\begin{array}{lr}\text { bertekstur, } & \text { tidak } \\
\text { licin, } & \text { dilengkapi } \\
\text { dengan } & \text { ubin } \\
\text { peringatan. } & \\
\text { Dilengkapi } & \text { hand } \\
\text { railing } & \\
\end{array}$ & $\begin{array}{l}\text { Kemiringan } \\
\text { cukup curam, } \\
\text { masih } \\
\text { menyulitkan } \\
\text { pengguna kursi } \\
\text { roda }\end{array}$ \\
\hline & Kesimpulan & $\begin{array}{l}\text { Aksesibilitas } \\
\text { cukup }\end{array}$ \\
\hline \multirow[t]{2}{*}{$\begin{array}{l}\text { Jalur } \\
\text { Pedestrian }\end{array}$} & $\begin{array}{l}\text { Permukaan harus } \\
\text { stabil, kuat, tahan } \\
\text { cuaca dan tidak } \\
\text { licin. Lebar min. } \\
150 \mathrm{~cm} \text { untuk } 1 \\
\text { arah dan min } 160 \\
\text { cm untuk jalur } 2 \\
\text { arah. Dilengkapi } \\
\text { kanstin dgn } \\
\text { ketinggian min. } 10 \\
\text { cm dan lebar } 15 \mathrm{~cm} \\
\text { Dilengkapi jalur } \\
\text { pemandu/penanda }\end{array}$ & $\begin{array}{l}\text { Ukuran } \\
\text { memenuhi standar } \\
\text { hanya tidak } \\
\text { terdapat jalur } \\
\text { pemandu.. } \\
\text { Beberapa bagian } \\
\text { terdapat hambatan } \\
\text { yang menyulitkan } \\
\text { pengguna } \\
\text { berkebutuhan } \\
\text { khusus. }\end{array}$ \\
\hline & Kesimpulan & $\begin{array}{l}\text { Aksesibilitas } \\
\text { cukup }\end{array}$ \\
\hline \multirow[t]{2}{*}{$\begin{array}{l}\text { Bangku } \\
\text { taman }\end{array}$} & $\begin{array}{l}\text { Permukaan } \\
\text { rata } \\
\text { Tinggi maks } \\
\text { dudukan } 45 \mathrm{~cm} \\
\text { Lebar dudukan } 60 \\
\text { cm, panjang } \\
\text { dudukan } 120 \mathrm{~cm}\end{array}$ & $\begin{array}{l}\text { Ukuran belum } \\
\text { sesuai dengan } \\
\text { standar. } \\
\text { Permukaannya } \\
\text { tidak rata, tanpa } \\
\text { perkerasan, Akses } \\
\text { menuju ke bangku } \\
\text { taman sulit bagi } \\
\text { pengguna alat } \\
\text { bantu, karena } \\
\text { jalur sirkulasi } \\
\text { terputus. }\end{array}$ \\
\hline & Kesimpulan & $\begin{array}{l}\text { Aksesibilitas } \\
\text { kurang }\end{array}$ \\
\hline \multirow[t]{2}{*}{$\begin{array}{l}\text { Rambu } \\
\text { dan } \\
\text { Marka }\end{array}$} & $\begin{array}{l}\text { Harus informatif } \\
\text { dan mudah } \\
\text { ditemukan } \\
\text { Terdapat rambu } \\
\text { dan marka penanda } \\
\text { bagi disabilitas } \\
\text { Penempatan harus } \\
\text { sesuai dan tepat } \\
\text { bebas pandangan }\end{array}$ & $\begin{array}{l}\text { Kurangnya } \\
\text { tersedianya rambu } \\
\text { dan marka sebagai } \\
\text { informasi bagi } \\
\text { pengunjung } \\
\text { terutama bagi } \\
\text { penyandang } \\
\text { disabilitas }\end{array}$ \\
\hline & Kesimpulan & $\begin{array}{l}\text { Aksesibilitas } \\
\text { kurang }\end{array}$ \\
\hline
\end{tabular}

Dari tabel di atas diketahui bahwa sarana dan fasilitas yang ada di Taman Samarendah belum sepenuhnya memenuhi standar aksesibilitas yang telah ditentukan oleh pemerintah. Tangga, ramp dan jalur pedestrian memiliki aksesibilitas yang cukup, artinya elemen tersebut memenuhi beberapa persyaratan aksesibilitas, namun masih ada yang belum sesuai seperti kemiringan yang 
curam, belum tersedian handrail dan jalur pemandu. Elemen yang memiliki aksesibilitas cukup ini masih dapat digunakan oleh sebagian besar pengunjung, namun masih sulit untuk beberapa pengunjung. Sedangkan elemen yang memiliki aksesibilitas kurang adalah parkir, bangku taman dan rambu/marka. Aksesibilitas kurang karena sebagian belum memenuhi sebagian besar persyaratan, bahkan tidak tersedia sama sekali. Dengan aksesibilitas yang kurang menyebabkan elemen taman tersebut sulit untuk digunakan terutama untuk penyandang disabilitas, hanya mudah untuk orang yang tidak memiliki kekurangan fisik.

Setelah diketahui aksesibilitas elemen-elemen taman kemudian dilakukan analisis untuk mengetahui implementasi 7 prinsip desain universal pada Taman Samarendah. Prinsip desain universal tersebut yaitu:

\section{Equitable use,}

Prinsip ini mensyaratkan semua sarana yang ada dapat digunakan oleh semua orang tanpa terkecuali meskipun memiliki kemampuan yang berbeda-beda. Sarana yang ada di area Taman Samarindah belum sepenuhnya dapat digunakan oleh semua orang. Belum disediakannya jalur pemandu untuk tuna netra dan parkir khusus untuk difable. Ramp dan tangga sudah cukup memenuhi standar aksesibilitas untuk penyandang disabilitas, lansia dan anak-anak. Furniture taman seperti bangku taman dan tempat sampah hanya dapat digunakan oleh orang normal, lansia dan anakanak, sedangkan untuk pengguna kursi roda, kruk dan tuna netra mengalami kesulitan untuk mengaksesnya.

Jalur pedestrian yang ada belum menjamin keamanan dan keselamatan bagi pengguna kursi roda, karena adanya beberapa jalur sirkulasi yang terputus akibat adanya perbedaan elevasi pedestrian yang cukup tinggi. Tangga dan ramp juga masih cukup berbahaya bagi pengguna kursi roda, karena kemiringannya yang terlalu curam. Adanya saluran drainase yang menjorok ke pedestrian juga menimbulkan bahaya bagi semua pengunjung, terlebih saluran ini tidak semua tertutup dengan aman.
Secara umum desain Taman Samarendah beserta elemen-elemen pendukungnya cukup menarik perhatian bagi warga Kota Samarinda, karena lokasinya berada di pusat kota sehingga mudah diakses, dan juga taman dilengkapi dengan air mancur, patung kuda dan lampu taman yang warnanya bisa berubah-ubah.

\section{Flexibility in use,}

Prinsip ini mengakomodasi berbagai keadaan dan kemampuan setiap individu, tujuannya untuk menyediakan beberapa pilihan dalam penggunaannya. Pengunjung Taman Samarendah diberikan beberapa pilihan akses masuk yang letaknya tersebar di sekeliling taman yang dilengkapi dengan tangga dan ramp. Hanya saja ramp yang ada belum sesuai dengan standar aksesibilitas, pengguna kursi roda masih sulit untuk mengaksesnya karena terlalu curam.

Area parkir yang ada juga cukup memberi pilihan lokasi bagi pengunjung karena terletak di sekeliling area taman. Jalur pedestrian yang ada di area taman terdiri dari beberapa tipe, kesemuanya memiliki ukuran yang mudah untuk diakses oleh semua orang dan materialnya kasar sehingga cukup aman. Hanya saja terdapat beberapa hambatan yang ada di jalur pedestrian. Bangku taman yang ada terdiri dari 2 tipe tetapi kesemuanya sulit diakses karena tidak ada jalur sirkulasi yang menghubungkan langsung.

\section{Simple and intuitive use,}

Prinsip ini mensyaratkan desain fasilitas taman harus mudah dimengerti dalam penggunaannya. Secara umum seluruh elemen taman yang ada memiliki desain yang sederhana sehingga mudah dimengerti oleh pengunjung, hanya saja beberapa masih sedikit menyulitkan bagi pengunjungnya. Akses masuk ke dalam taman cukup mudah dikenali oleh pengunjung terlebih letaknya yang menyebar mengelilingi area taman memberi kemudahan bagi pengunjung untuk memasuki area taman. Tangga dan ramp yang ada di akses masuk memiliki desain yang cukup sederhana namun belum memudahkan bagi penyandang disabilitas, karena belum memenuhi standar aksesibilitas, terlebih tidak 
tersedia rambu atau marka yang memberi informasi pada pengunjung.

Pola jalur pedestrian menggunakan bentukbentuk kurva menyebar keseluruh area taman. Desain ini cukup sederhana dan mudah digunakan bagi pengunjung normal dan penyandang disabilitas, kecuali bagi tuna netra, karena tidak tersedia jalur pemandu sebagai pengarah. Tidak tersedianya rambu atau marka yang memberi informasi kepada pengunjung untuk mempermudah dalam menggunakan fasilitas yang ada, terutama rambu khusus bagi difable. Rambu atau marka penting bagi pengunjung sebagai informasi untuk membantu pengunjung dalam melakukan aktivitasnya di area taman, sehingga fasilitas yang mudah ditemukan dan mudah digunakan,

\section{Perceptible information,}

Prinsip desain universal ini mensyaratkan agar Taman Samarendah dilengkapi dengan informasi pendukung yang penting untuk pengguna. Area parkir yang ada telah dilengkapi dengan petunjuk parkir dan garis pembatas parkir, meskipun saat ini pola parkirnya sudah agak samar terlihat karena kurangnya perawatan, namun belum adanya simbol parkir khusus untuk difable.

Simbol aksesibilitas juga sudah ada pada seluruh ramp yang ada. Tulisan atau gambar yang memberi petunjuk arah pada jalur pedestrian sama sekali tidak ditemukan di seluruh area taman, begitu juga simbol-simbol fasilitas untuk difable tidak ada. Papan petunjuk yang memberikan informasi tentang letak sarana di area taman tidak ditemukan, terlebih lagi petunjuk berupa suara sama sekali tidak tersedian di Taman Samarendah. Informasi yang ada hanya berupa ramburambu tentang kawasan bebas rokok dan dilarang buang sampah.

\section{Tolerance for error,}

Prinsip desain universal ini mensyaratkan agar desain yang ada di Taman Samarendah meminimalkan bahaya dan kerugian akibat kecelakaan atau kejadian yang tidak disengaja. Masih terjadi beberapa kesalahan desain di area taman yang dapat menimbulkan bahaya bagi penggunanya. Pada sambungan antar jalur pedestrian terdapat perbedaan ketinggian permukaannya yang menyebabkan putusnya jalur sirkulasi terutama untuk pengguna kursi roda, tetapi bagi pengunjung normal masih dapat menggunakannya.

Terdapat beberapa saluran drainase yang terbuka dapat menyebabkan kecelakaan bagi pengunjung terutama anak-anak dan yang memiliki keterbatasan fisik. Bangku taman yang ada di Taman Samarendah sulit diakses karena tidak tersedia jalur sikulasi yang langsung menuju ke bangku taman. Selain itu kurang tersedianya marka sebagai penunjuk arah dan peringatan cukup menyulitkan pengunjung ketika beraktivitas di area taman.

\section{Low physical effort,}

Prinsip ini mensyaratkan agar sarana yang ada dapat digunakan secara efisien dan nyaman dalam segala kondisi. Pada Taman Samarendah masih banyak elemen-elemen ruang luarnya yang beresiko menimbulkan bahaya atau kecelakaan. Area parkir yang bersisian langsung dengan jalan raya dengan intensitas tinggi menimbulkan bahaya pengunjung tersenggol kendaraan yang lewat, terlebih tidak adanya jalur khusus pejalan kaki menuju ke akses masuk taman.

Tidak tersedianya handrail pada tangga beresiko terjadinya cedera atau kecelakaan bagi pengguna kruk, orang tua bahkan tuna netra, terlebih tidak adanya jalur pemandu pada tangga dan jalur pedestrian. Pada jalur pedestrian di dalam area taman juga terdapat beberapa bahaya yaitu adanya perbedaan elevasi, saluran drainase yang mengganggu sirkulasi.

\section{Size and space for approach and use.}

Prinsip desain universal ini mensyaratkan penggunaan ukuran ruang dalam desain yaitu dengan melakukan pendekatan postur, ukuran dan pergerakan pengguna. Berdasarkan analisis aksesibilitas yang telah dilakukan di atas, Taman Samarendah sebagian sudah memenuhi prinsip desain universal ini. Lebar jalur pedestrian yang ada sudah sesuai dengan standar aksesibilitas dan juga menggunakan material yang permukaan kasar sehingga tidak berbahaya bagi penyandang disabilitas. Dengan kondisi demikian jalur pedestrian ini 
cukup nyaman gunakan oleh semua pengunjung tanpa terkecuali. Ukuran tangga juga sudah sesuai dengan standar aksesibilitas namun belum ada handrail-nya, sedangkan untuk ramp lebarnya sudah memenuhi standar namun kemiringannya yang masih terlalu curam.

Hasil analisis penerapan prinsip desain universal tercantum pada tabel berikut ini:

Tabel 2.

Hasil Analisis Penerapan Prinsip Desain Universal

\begin{tabular}{|l|c|c|c|c|c|c|c|}
\hline \multirow{2}{*}{ Elemen } & \multicolumn{7}{|c|}{ 7 Prinsip Desain Universal } \\
\cline { 2 - 8 } & (1) & (2) & (3) & (4) & (5) & (6) & (7) \\
\hline $\begin{array}{l}\text { Akses } \\
\text { masuk }\end{array}$ & $\checkmark$ & $\checkmark$ & $\checkmark$ & $\mathbf{x}$ & $\mathbf{x}$ & $\mathbf{x}$ & $\checkmark$ \\
\hline $\begin{array}{l}\text { Area } \\
\text { Parkir }\end{array}$ & $\mathbf{x}$ & $\checkmark$ & $\checkmark$ & $\checkmark$ & $\mathbf{x}$ & $\mathbf{x}$ & $\checkmark$ \\
\hline Tangga & $\mathbf{x}$ & $\mathbf{x}$ & $\checkmark$ & $\mathbf{x}$ & $\mathbf{x}$ & $\mathbf{x}$ & $\checkmark$ \\
\hline Ramp & $\mathbf{x}$ & $\checkmark$ & $\checkmark$ & $\checkmark$ & $\mathbf{x}$ & $\mathbf{x}$ & $\checkmark$ \\
\hline Pedestrian & $\checkmark$ & $\checkmark$ & $\checkmark$ & $\mathbf{x}$ & $\mathbf{x}$ & $\mathbf{x}$ & $\checkmark$ \\
\hline Bangku & $\mathbf{x}$ & $\mathbf{x}$ & $\mathbf{x}$ & $\mathbf{x}$ & $\mathbf{x}$ & $\mathbf{x}$ & $\mathbf{x}$ \\
\hline $\begin{array}{l}\text { Marka \& } \\
\text { Rambu }\end{array}$ & $\checkmark$ & $\mathbf{x}$ & $\mathbf{x}$ & $\mathbf{x}$ & $\mathbf{x}$ & $\mathbf{x}$ & $\mathbf{x}$ \\
\hline
\end{tabular}

Dari tabel di atas diketahui bahwa belum semua elemen-elemen yang ada di Taman Samarendah memenuhi prinsip desain universal sehingga perlu adanya perbaikan sarana dan fasilitas taman kota agar ramah bagi semua orang tanpa terkecuali. Prinsip desain universal yang paling banyak tidak terpeduhi adalah prinsip tolerance for error dan prinsip low phsycal effort, sedangkan prinsip yang paling banyak diterapkan adalah size and space for approach and use. Sedangkan dilihat dari elemen-elemen taman kota yang ada, yang paling kurang menerapkan prinsip desain universal adalah marka/rambu, bangku taman dan tangga. Elemen-elemen ini perlu diperbaiki dan disesuaikan dengan standar yang telah ditentukan agar ramah untuk semua orang tanpa terkecuali.

\subsection{Arahan Desain}

Berdasarkan hasil analisis dan pengamatan pada Taman Samarendah diketahui bahwa fasilitas-fasilitas yang ada sebagian besar belum menerapkan prinsip desain universal. Untuk itu diperlukan arahan desain sebagai upaya berbaikan elemen-elemen taman kota yang ada Di Samarinda. Arahan desain ini mengacu pada Permen PUPR No. 14 Tahun 2017 mengenai persyaratan kemudahan bangunan dan Gedung dan juga mengacu pada Universal Design Guide for Public Places.

\subsubsection{Akses masuk}

Akses masuk ke dalam area taman harus bebas dari hambatan, tidak boleh terhalangi oleh parkir. Pada akses masuk juga harus dilengkapi dengan rambu atau marka sebagai informasi bagi pengunjung.

\subsubsection{Area parkir}

Pada area parkir perlu disediakan dropping area untuk pengunjung, agar lebih aman dalam mengakses ke dalam area taman. Perlu disediakan jalur pedestrian yang dilengkapi dengan jalur pemandu dari parkir menuju akses masuk ke area taman. Perlu adanya garis pembatas parkir yang membagi area parkir berdasarkan jenis kendaraan. Parkir khusus penyandang disabilitas harus tersedia yaitu berjumlah $2 \%$ dari area parkir seluruhnya.

\subsubsection{Tangga}

Ketinggian dan lebar anak tangga sudah sesuai namun perlu menambahkan handrail yang memenuhi standar ergonomis yang aman, nyaman untuk digenggam dan bebas dari permukaan tajam dan kasar dan sebaiknya dilengkapi dengan huruf braille sebagai informasi bagi penyandang tuna netra. Lebar anak tangga minimal $30 \mathrm{~cm}$ dan pada bagian tepi tangga diberi material anti slip.

\subsubsection{Ramp}

Kemiringan masih ramp yang ada masih terlalu curam, sehingga perlu diperpanjang hingga kemiringannya maksimal $6^{0}$. Penambahan handrail yang memenuhi standar ergonomis yang aman dan nyaman untuk digenggam. Perlu disediakan jalur pemandu untuk tuna netra.

\subsubsection{Jalur Pedestrian}

Jalur pedestrian di Taman Samarendah Perlu dilengkapi jalur pemandu untuk penyandang tuna netra. Dan juga perlu dihilangkan perbedaan elevasi pada sambungan jalur pedestrian, sehingga jalur sirkulasinya menerus terhubung langsung dengan sarana dan fasilitas yang ada di area taman. Jalur pedestrian perlu dilengkapi dengan tepi 
pengaman/kanstin dengan ketinggian $10-15$ $\mathrm{cm}$, fungsinya sebagai penghentian kursi roda dan tongkat penyandang tuna netra agar terhidar dari area yang berbahaya.

\subsubsection{Bangku Taman}

Bangku taman diberi sandaran punggung dan ukurannya disesuai dengan standar aksesibilitas. Permukaan harus rata, dan diberi jalur sirkulasi yang menuju langsung ke bangku taman, sehingga mudah untuk diakses oleh semua pengunjung.

\subsubsection{Rambu dan Marka}

Seluruh area Taman harus dilengkapi dengan rambu dan marka yang informatif dan mudah dikenali oleh semua penggunjung. Perlu disediakan rambu dan marka penanda bagi penyandang disabilitas berupa rambu arah dan tujuan pada jalur pedestrian, rambu parkir penyandang disabilitas, dan rambu huruf timbul/braille. Penempatan rambu harus sesuai dan tepat serta bebas pandangan tanpa penghalang serta cukup mendapat pencahayaan.

\section{KESIMPULAN}

Berdasarkan hasil analisis yang telah dilakukan dapat diambil kesimpulan bahwa Taman Samarendah belum sepenuhnya menerapkan prinsip desain universal dan juga belum sesuai dengan standar aksesibilitas yaitu Permen PUPR No. 14 tahun 2017. Terlihat dari elemen-elemen taman yang belum ramah terhadap seluruh pengunjung. Pengunjung dengan keterbatasan fisik berupa pengguna alat bantu gerak dan tuna netra yang paling banyak mengalami kesulitan dalam memanfaatkan seluruh sarana dan fasilitas yang ada di area taman. Temuan penelitian ini yaitu dari tujuh elemen taman kota yang dianalisis semua belum menerapkan prinsip desain universal secara menyeluruh. Prinsip desain universal yang paling banyak tidak terpenuhi adalah prinsip tolerance for error dan prinsip low phsycal effort, sedangkan prinsip yang paling banyak diterapkan adalah size and space for approach and use. Sedangkan dilihat dari elemen-elemen taman kota yang ada, yang paling kurang menerapkan prinsip desain universal adalah marka/rambu, bangku taman dan tangga. Dengan kondisi yang ada maka disampaikan beberapa rekomendasi sebagai usulan terkait dengan implementasi desain universal pada taman kota di Samarinda : (1) Perlu perbaikan elemen Taman Samarendah disesuaikan dengan standar aksesibilitas dan prinsip desain universal; (2) Meningkatkan kesadaran publik terhadap isu desain universal; (3) Pemerintah dapat menyusun peraturan daerah untuk memperkuat peraturan pemerintah yang sudah ada; (4) Perencanaan yang matang untuk fasilitas publik dengan memperhatikan standar aksesibilitas dan prinsip desain universal; (5) Kontrol terhadap proses perwujudan desain universal fasilitas publik dengan melibatkan kaum difable.

Dengan implementasi desain universal yang semakin luas diharapkan meningkatnya kualitas hidup seluruh masyarakat Kota Samarinda, karena Taman Kota merupakan salah satu kawasan ruang terbuka publik kota yang dapat mewadahi aktivitas seluruh masyarakat kota secara optimal tanpa terkecuali.

\section{REFERENSI}

Anon., 2016. Universal Design Guidlines for Public Places. Singapore: Building and Construction Authority.

Budiyanti, R. B., 2018. Sebuah Tinjauan Taman Kota Sebagai Ruang Terbuka Publik Bagi Warga Disabilitas: Peluang dan Tantangan. Jurnal Kota Layak Huni, pp. 61-69.

Dewang, N. \& Leonardo, 2010. Aksesibilitas Ruang Terbuka Publik Bagi Kalangan Masyarakat Tertentu Studi Fasilitas Publik Bagi Kaum Difable di Kawasan Taman Untuk Suropati Menteng-Jakarta Pusat. Jurnal PLANESA, Mei, Volume Vol. 1 No. 1, pp. 8 -18.

Imansari, N. \& Khadiyanta, P., 2015. Penyediaan Hutan Kota dan Taman Kota Sebagai Ruang Terbuka Hijau (RTH) Publik Menurut Preferensi Masyarakat di Kawasan Pusat Kota Tangerang. Jurna Ruang, pp. 101 - 110.

Irkhamiyati, 2017. Evaluasi Persiapan Perpustakaan Stikes 'Aisyiyah Yogyakarta Dalam Membangun Perpustakaan Digital. Jurnal Berkala 
Ilmu Perpustakaan dan Infomasi, Volume 13 No. 1, pp. 37-46.

Keumala, C. R. N., 2016. Pengaruh Konsep Desain Universal Terhadap Tingkat Kemandirian Difabel : Studi Kasus Masjid UIN Sunan Kalijaga dan Masjid Kampus Universitas Gajah Mada. INKLUSI: Journal of Disability Studies, pp. 19-39.

Kurniawan, Harry, 2014. Implementasi Aksesibilitas Pada Gedung Baru Perpustakaan UGM. Indonesian Journal of Disability Studies, 1(1), pp. 44-51.

Lubis, H. A. K. H., 2008. Kajian Aksesibilitas Difabel Pada Ruang Publik Kota. Studi Kasus: Lapangan Merdeka, Medan: Universitas Sumatera Utara .

Masruroh, F., Mauliani, L. \& Anisa, 2015. Kajian Prinsip Universal Design yang Mengakomodasi Aksesibilitas Difabel. Studi Kasus Taman Menteng. Jurnal Jurusan Arsitektur Fakultas Teknik Universitas Muhammadiyah Jakarta, pp. 3-4.

Mulyandari, H., 2010. Pengantar Arsitektur Kota. Yogyakarta: Penerbit Andi. 